\title{
THE INCIDENCE OF SUBSTANCES IN THE SERA OF FERTILE AND INFERTILE WOMEN AGGLUTINATING SEMINAL PLASMA- COATED PARTICLES
}

\author{
AUDREY P. WARD, ${ }^{*}$ KAY CAPNER $\dagger$ AND WENDY JEFFERY $\ddagger$ \\ Department of Obstetrics and Gynaecology, St Mary's Hospital, London, W.2, \\ and $\ddagger$ Lister Institute of Preventive Medicine, Elstree, Herts.
}

(Received 28th September 1972)

\begin{abstract}
Summary. Substances agglutinating seminal plasma-coated particles were present more frequently and in higher titres in the sera of infertile than of fertile women. There is evidence that the agglutinating substance is not anti-seminal antibody, and that this test is of no value as an aid to the diagnosis of allergic infertility.
\end{abstract}

\section{INTRODUCTION}

In some women in whom the usual clinical investigations have revealed no abnormality either in them or in their husbands, infertility has been attributed to allergy. Antibodies agglutinating spermatozoa have been found in the sera of infertile women more often and in higher titre than in fertile women (Franklin \& Dukes, 1964a, b; Schwimmer, Ustay \& Behrman, 1967; Glass \& Vaidya, 1970; Ansbacher, Manarang-Pangan \& Srivannaboon, 1971). Some antisperm antibodies are cytotoxic, immobilizing or even disrupting the spermatozoa (Parish, Carron-Brown \& Richards, 1967; Parish \& Ward, 1968; Isojima, Li \& Ashitaka, 1968; Ansbacher et al., 1971), and the cytotoxic antibody in the serum and cervical mucus was shown to be complement-fixing IgG (Parish \& Ward, 1968).

Women forming antibodies to sperm cells are also likely to form antibodies to seminal plasma substances which are firmly adsorbed by the spermatozoa. Seminal plasma can be easily stored and used at any time in laboratory tests, whereas suitable fresh semen or suspensions of spermatozoa are not always available. The sera of fertile and infertile women were tested for antibodies to seminal plasma to determine whether such a test would prove to be an aid to the diagnosis of allergic infertility.

\footnotetext{
* Present address: St James Hospital, Tredegar and Nevill Hall Hospital, Abergavenny, Monmouthshire.

$\dagger$ Present address: St Mary's Hospital, London, W.2.

$\ddagger$ Present address: Department of Experimental Pathology, The Medical School, St Mary's Hospital, London, W.2.
} 


\section{MATERIALS AND METHODS}

Sera

Blood samples were obtained from patients admitted to the Samaritan Hospital for Women. The patients included those who were being investigated for infertility, in some of whom no cause for infertility was known, and fertile women who had had several children without difficulty in conceiving and who had subsequently been admitted for sterilization, hysterectomy, repair or diagnostic dilatation and curettage. Samples were also obtained from seven women who were virgo intacta.

\section{Tanned cell agglutination test for antibodies to seminal plasma}

Seminal plasma was adsorbed to the surface of human Group O red cells by the method of Boyden (1951) as modified by Jeffery \& Parish (1972). Seminal plasma was obtained from blood Group $\mathrm{O}$ men, or from non-secretor group $\mathrm{A}$ and $\mathrm{B}$ men and demonstrated to contain no A or B antigen by its failure to reduce the titre of anti-A or anti-B red cell agglutinins. The centrifuged cell-free plasma was dialysed against $0.001 \mathrm{M}$-EDTA in $0.05 \mathrm{M}$-tris buffer in $0.9 \% \mathrm{NaCl}$ overnight at $4^{\circ} \mathrm{C}$ to remove the tendency of untreated seminal plasma to clump red cells. It was then diluted $1 / 10$, and stored frozen.

A 4\% suspension of washed human Group $O$ red cells was treated with an equal volume of a $1 / 50$ dilution of $0.5 \%$ tannic acid for $30 \mathrm{~min}$. The cells were washed three times and resuspended as a $2 \%$ suspension, which was treated with an equal volume of the treated, diluted, seminal plasma for $45 \mathrm{~min}$. The cells were again washed three times and resuspended to $1 \%$ in buffered saline, $\mathrm{pH}$ $7 \cdot 0$, containing $1 / 50$ horse serum, previously inactivated and adsorbed with Group $\mathrm{A}$ and Group $\mathrm{O}$ human red cells.

The test sera were heated at $56^{\circ} \mathrm{C}$ for $30 \mathrm{~min}$ to destroy haemolytic complement and diluted in doubling dilutions in saline containing $1 / 50$ horse serum. An equal $0 \cdot 1-\mathrm{ml}$ volume of the antigen-coated red cell suspension was added, mixed, and the cells allowed to settle. A rabbit anti-seminal plasma antibody was titrated with each test as a positive control, and tubes of diluent as the negative control.

Agglutination observed in the tests was not due to anti-A or anti-B antibodies because the seminal plasma antigen did not contain blood Group A or B substances. It did not neutralize anti-A or anti-B antisera, and anti-A or anti-B antisera did not agglutinate tanned cells coated with seminal plasma.

In adsorption tests, $0 \cdot 1 \mathrm{ml}$-packed washed cells was added to $1 \mathrm{ml}$ undiluted sera.

In the further tests (Table 2), the human $O$ and sheep red cells after agglutination were tested with anti-human IgG and IgM antiglobulin sera. The antiIgG (rheumatoid-type) factors were examined by standard techniques with sheep red cells sensitized with non-agglutinating rabbit anti-sheep red cell serum, and human Group $O$ rhesus positive cells sensitized with non-agglutinating human IgG anti-D. Tests for antibodies to other blood groups were made by Dr Carolyn Giles of the Blood Group Reference Laboratory. 


\section{RESULTS}

Antibodies, or other substances, agglutinating red cells coated with seminal plasma were found more frequently and in greater amounts in the sera of infertile than of fertile women. Titres greater than $1 / 4$ were found in eight of fortyseven infertile women, and in seven of eighty-two fertile women (Text-fig. 1). The difference between the two groups is more evident at titres greater than 1/64 which were found only in infertile women. The agglutinating substance was present in two of the seven women who were virgo intacta, at $1 / 4$ and $1 / 16$, and was present in insignificant amounts in prostitutes, at $1 / 2$ or less, presumed to be frequently exposed to the antigen.

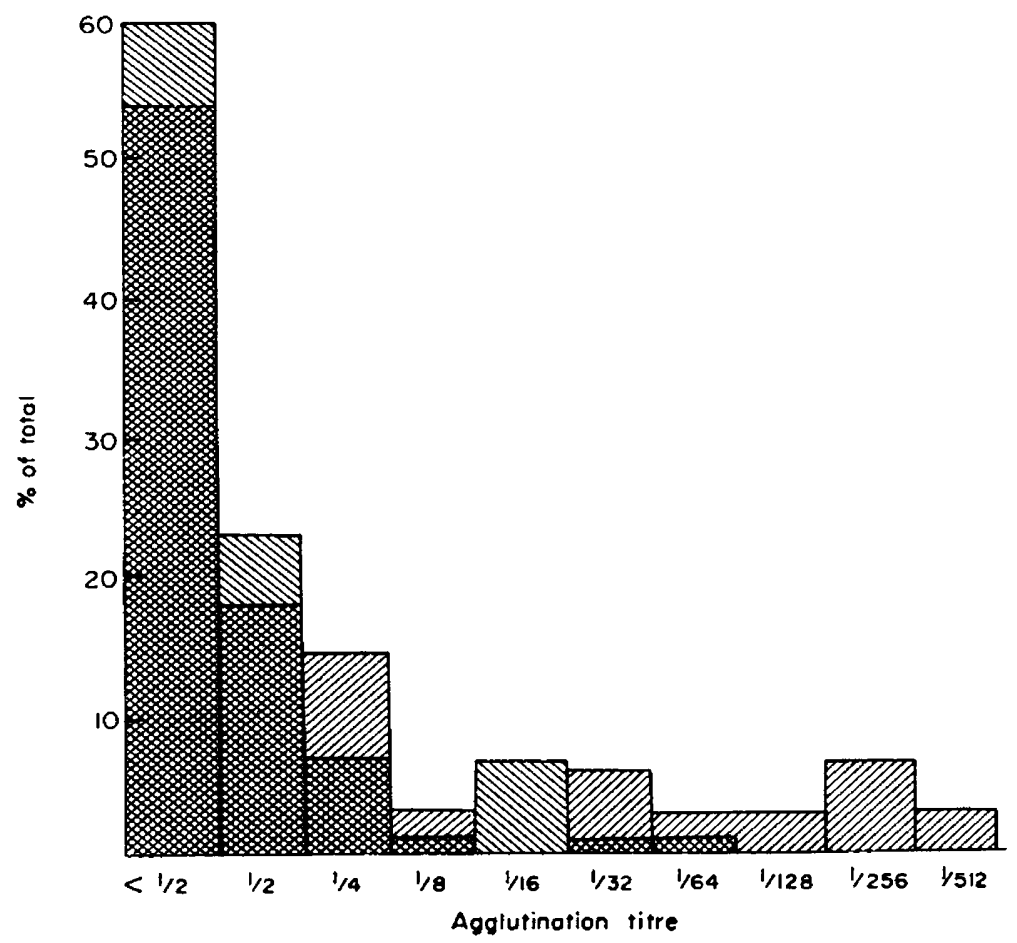

Text-FIG. 1. Incidence, expressed as a percentage, and titre of agglutination, in the sera of forty-seven infertile and eighty-two fertile women. Hatched lines sloping right represent infertile, and those sloping left represent fertile, women.

Possibility that substances other than antibody agglutinate the seminal plasma-coated particles

The agglutination of the seminal plasma-coated red cells was not due to anti-blood Group A or B antibodies in the sera reacting with A or B substance in the plasma. As described in 'Materials and Methods', no A or B antigen in the seminal plasma was detected by neutralization of anti-A or anti-B antibodies, and anti-A or anti-B antibodies did not agglutinate the seminal plasmacoated red cells. It was surprising, therefore, that the agglutinating titre for seminal plasma was reduced two dilutions or more when the sera were pre- 
viously adsorbed with Group $\mathrm{A}, \mathrm{B}$ or $\mathrm{O}$ cells, though there was no relation between the blood groups of the women and the ability of the cells to reduce the titre of anti-seminal plasma agglutinins (Table 1). This is also evident from the drop in titre of seminal plasma agglutination in the sera of twelve of twenty-one Group $\mathrm{O}$ infertile women adsorbed with Group A cells, but not in any of six Group B infertile women whose sera also contain anti-A antibodies.

In four sera selected for further tests (Table 2), there was no evidence that the cells adsorbing out the seminal-plasma agglutinating activity contained antigens also present in seminal plasma. The effect was therefore antigen non-specific, on the following evidence. (1) Two of the four sera had no signifi-

Table 1. The number of female sera in which the anti-seminal plasma titre was reduced by adsorbing with human A, B and O cells

\begin{tabular}{l|c|c|c|c|c|c}
\hline & \multicolumn{3}{|c|}{ Fertile women } & \multicolumn{3}{c}{ Infertile women } \\
\cline { 2 - 4 } $\begin{array}{l}\text { Blood } \\
\text { group }\end{array}$ & \multirow{2}{*}{ No. } & \multicolumn{2}{|c|}{ No. with drop in titre } & \multirow{2}{*}{ No. } & \multicolumn{2}{c}{ No. with drop in titre } \\
\cline { 3 - 6 } & & Ads. $O$ & Ads. $A B$ & & Ads. O & Ads. $A B$ \\
\hline O & 30 & 3 & 8 & 21 & 1 & 11 \\
A & 21 & 0 & 0 & 13 & 2 & 0 \\
B & 13 & 0 & 1 & 6 & 0 & 0 \\
AB & 18 & 1 & 1 & 7 & 2 & 1 \\
\hline
\end{tabular}

Ads. $\mathrm{O}=$ adsorbed with Group $\mathrm{O}$ cells; Ads. $\mathrm{AB}=$ adsorbed with Group AB cells.

cant anti-A or anti-B antibodies, yet $\mathrm{A}$ and $\mathrm{B}$ cells removed the seminal-plasma agglutinating activity. (2) There was no antibody to Group $\mathrm{O}$ cells by direct or by antiglobulin agglutination tests, yet $\mathrm{O}$ cells removed most of the seminalplasma agglutinating activity from two sera. (3) The agglutinating or antiglobulin titres to sheep cells were not related to the ability of sheep cells to adsorb seminal-plasma agglutinating activity. (4) Tests for antibodies to other blood groups that could theoretically be responsible for seminal-plasma agglutination showed only anti- $\mathrm{P}_{1}$ in one sera and anti-I in another, too weak to agglutinate the seminal plasma-coated particles.

It was also ascertained that the agglutination was not due to rheumatoid-type factors reacting with aggregated globulins in the antigen, because none of the four sera contained such factors when tested with rabbit globulin or human IgG (anti-D).

It is concluded, therefore, that the adsorption of the seminal plasma agglutinating activity from sera by the red cells is not due to antigens on the red cells corresponding to antigens in the seminal plasma. As the adsorption was antigen non-specific, the agglutination of the seminal plasma-coated particles by some sera is also likely to be antigen non-specific and not due to antibody which is antigen-specific.

\section{DISCUSSION}

The results confirm earlier reports that the sera of some women agglutinate 


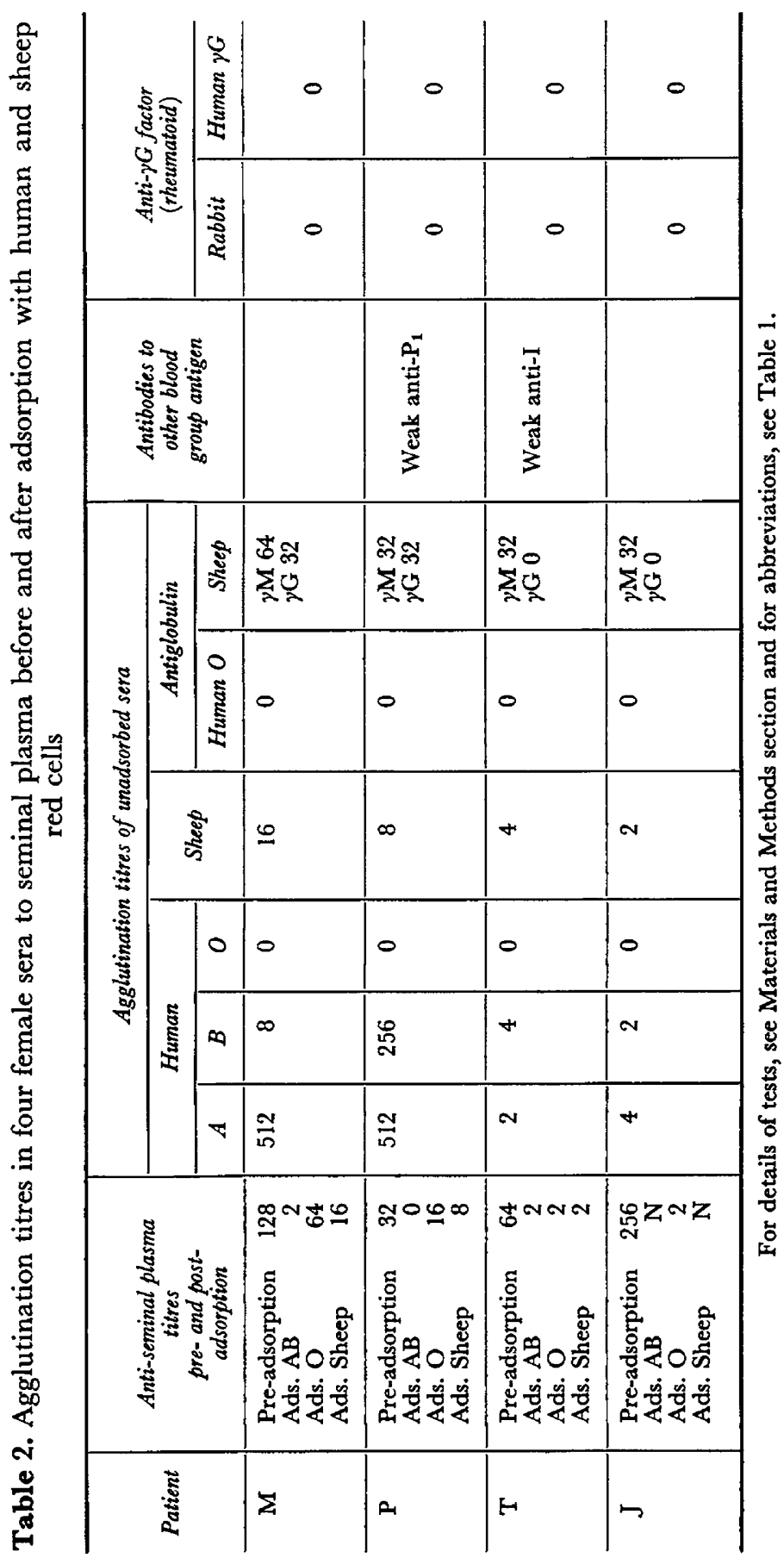


tanned red cells coated with seminal plasma or seminal antigens (Nakabayashi, Tyler \& Tyler, 1961; Southam, 1963; Schwimmer et al., 1967). Though Nakabayashi et al. (1961) found no agglutinins in unmarried women, but detected their presence in $18 \%$ of 368 infertile persons, our results agree more with those of Southam (1963) who also found agglutinins to seminal plasma in thirty-one of fifty-one pregnant women.

The partial or complete removal of the substances agglutinating the seminal plasma-coated cells from the sera by adsorption with human or sheep red cells is strong evidence that the agglutinating substance is not antibody to seminal plasma. This supports the statement by Southam (1963) that though thirty-one sera agglutinated cells coated with seminal plasma, only three agglutinated cells coated with sperm extracts. Moreover, Jeffery \& Parish (1972) found that results of tests for agglutinins to seminal plasma were unrelated to results of tests detecting antibodies to spermatozoa by agglutination, mixed-cell antiglobulin, immunofluorescence and cytotoxic tests. A non-antibody spermagglutinating substance has been detected by fractionation of one human serum (Boettcher \& Kay, 1969).

It was considered that the non-antibody agglutinating factor for seminal plasma, removable by adsorption with sheep or human Group $\mathrm{O}$ red cells, might be an antibody that combined with a serum protein on the red cells sharing antigenic determinants with seminal plasma. For instance, scaferrin of seminal plasma shares antigenic determinants with lactoferrin (Roberts \& Boettcher, 1969) and might do so with serum transferrin. However, if the red cells had removed a cross-reacting antibody, then after adsorption, they should be agglutinated by antiglobulin sera, because the antiglobulin would combine with the antibody taken up from the anti-seminal plasma serum by the red cells. In practice (Table 2), though the sheep red cells were found to have adsorbed antibody when tested with antiglobulin sera, the human Group $\mathrm{O}$ red cells, which also greatly reduced the anti-seminal plasma agglutination, had adsorbed no antibody detected by the antiglobulin serum. The agglutinating factor for seminal plasma removed by human Group $\mathrm{O}$ red cells was unlikely, therefore, to be antibody globulin.

Antibodies of all three classes, IgG, IgA and IgM, which react with spermatozoa or seminal plasma, have been found in human sera or cervical mucus (Parish \& Ward, 1968) and it is possible that the greater incidence and higher titres found in the sera of infertile women in the results reported above reflect concomitant antibodies and non-antibody-agglutinating substances in these sera. We conclude that the tanned cell agglutination test is of no value in the diagnosis of allergic infertility.

\section{ACKNOWLEDGMENTS}

We gratefully acknowledge the help and guidance of Dr W. E. Parish, Head of Research, Lister Institute of Preventive Medicine, Elstree. We also thank Dr Garolyn M. Giles of the Blood Group Reference Laboratory for her help in detecting the anti- $\mathrm{P}_{1}$ and anti-I groups. 


\section{REFERENGES}

Astidacher, R., Manarang-Pangan, S. \& Srivannaboon, S. (1971) Sperm antibodies in infertile couples. Fert. Steril. 22, 298.

BoetTcher, B. \& KAY, D. J. (1969) Fractionation of a human spermagglutinating serum. Nature, Lond. 223, 737.

Boyden, S. V. (1951) The adsorption of proteins on erythrocytes treated with tannic acid and subsequent hemagglutination by anti-protein sera. 7. exp. Med. 93, 107.

Franklin, R. R. \& Dukes, C. D. (1964a) Antispermatozoal antibody and unexplained infertility. Am. 7. Obstet. Gynec. 89, 6.

FRANKLIN, R. R. \& Dukes, C. D. (1964b) Further studies on sperm-agglutinating antibody and unexplained infertility. F. Am. med. Ass. 190, 682.

Glass, R. H. \& Vaidya, R. A. (1970) Sperm-agglutinating antibodies in infertile women. Fert. Steril. 21, 657.

Isojıma, S., LI, T. S. \& Ashitaka, Y. (1968) Immunologic analysis of sperm-immobilizing factor found in sera of women with unexplained sterility. Am. F. Obstet. Gynec. 101, 677.

Jeffery, W. \& Parish, W. E. (1972) Allergic infertility: laboratory techniques to detect antispermatozoal antibodies. Clin. Allergy, 2, 261.

Nakabayashi, N. T., Tyler, E. T. \& Tyler, A. (1961) Immunologic aspects of human infertility. Fert. Steril. 12, 544.

Parish, W. E., Carron-Brown, J. A. \& Richards, C. B. (1967) The detection of antibodies to spermatozoa and to blood group antigens in cervical mucus. F. Reprod. Fert. 13, 469.

PARISH, W. E. \& WARD, A. (1968) Studies of cervical mucus and serum from infertile women. F. Obstet. Gynaec. Br. Commonw. 75, 1089.

Roberts, T. K. \& BoetTCHER, B. (1969) Identification of human sperm-coating antigen. F. Reprod. Fert. 18, 347.

Schwimmer, W. B., Ustay, K. A. \& Behrman, S. J. (1967) An evaluation of immunologic factors in infertility. Fert. Steril. 18, 167.

Southam, A. L. (1963) Clinical significance of antibodies to spermatozoa and seminal plasma. $\mathcal{F}$. Reprod. Fert. 5, 458. 